\title{
Membaca Realitas Infodemi Covid-19 di Indonesia
}

\author{
Aurelius Rofinus Lolong Teluma \\ Universitas Mataram, Indonesia, aureliusteluma@unram.ac.id

\section{A Reading on Indonesia's Covid-19 Infodemic Reality}

\begin{abstract}
The Covid-19 Infodemic is a massive flood of information, both accurate and inaccurate, making it difficult for people to find reliable sources and guidance when they need it to overcome Covid-19's disease. This paper seeks to read the reality of infodemic in Indonesia by processing and to restate and to interpret data from the Covid19 Infodemics Observatory project on the dynamics of Indonesian citizens' tweets concerning Covid-19 for the period January 21, 2020 - July 22, 2020. The data can be obtained freely on the https://covid19obs.fbk.eu/\#/. The analysis shows that globally, from January 21 to July 22, 2020, there were more than 365 million tweets related to Covid-19. In Indonesia, the highest number of infodemic tweets produced was 114,000 tweets per day on March 15, 2020. Even so, only 608 tweets were confirmed as reliable facts, and 87 tweets were verified as unreliable facts. There are still too few tweets that are categorized as reliable facts, and there are still many that are classified as unreliable facts. It has led to the high Infodemic Risk Index in Indonesia, reaching the level of 0.77 from the scale of $0.00-1.00$ on January 25, 2020. The large gap between the number of tweets and news reliability occurred during the Covid-19 pandemic from January to July 2020.
\end{abstract}

Keywords: Covid-19; Infodemics; Infodemics Risk Index

\begin{abstract}
ABSTRAK
Infodemi Covid-19 merupakan banjir besar informasi, baik akurat maupun tidak, yang membuat orang kesulitan menemukan sumber dan panduan terpercaya saat mereka membutuhkannya untuk mengatasi penyakit Covid-19. Tulisan ini berupaya membaca realitas infodemi di Indonesia dengan mengolah dan menyajikan kembali serta menafsir data Covid19 Infodemics Observatory tentang dinamika kicauan warganet Indonesia terkait Covid-19 periode 21 Januari 2020 - 22 Juli 2020. Data tersebut dapat diperoleh secara bebas pada laman https://covid19obs.fbk.eu/\#/. Hasil analisis menunjukkan bahwa secara global, sejak 21 Januari hingga 22 Juli 2020, terdapat lebih dari 365 juta tweets terkait Covid-19. Di Indonesia, jumlah kicauan infodemik tertinggi yang dihasilkan adalah 114.000 tweets per hari yakni pada tanggal 15 Maret 2020. Sekalipun demikian, hanya 608 tweets yang terkonfirmasi sebagai berita layak dipercaya, dan 87 tweets yang terverifikasi sebagai berita yang tidak layak dipercaya. Masih terlalu sedikit kicauan yang terkategorikan sebagai reliable facts dan masih banyak yang tergolong sebagai unreliable facts. Hal inilah yang mengakibatkan tingginya Indeks Resiko Infodemik di Indonesia hingga menyentuh level 0,77 dari skala $0.00-1.00$ pada tanggal 25 Januari 2020. Kesenjangan yang besar antara jumlah tweets dengan reliabilitas beritanya tersebut berlangsung selama pandemi Covid-19 dari Januari hingga Juli 2020.
\end{abstract}

Kata kunci: Covid-19; Infodemi; Indeks Resiko Infodemik

\section{Pendahuluan}

"Kami tidak hanya memerangi pandemi, kami sedang berjuang melawan infodemi." Begitulah pernyataan Dr. Tedros Adhanom Ghebreyesus, Direktur Jenderal Organisasi Kesehatan Dunia (WHO), dalam sambutannya di Konferensi Keamanan Dunia, Muenchen, Jerman, 15 Februari 2020. Menurut WHO, infodemi (infodemic) adalah banjir informasi, baik 
akurat maupun tidak, yang membuat orang kesulitan menemukan sumber dan panduan tepercaya saat mereka membutuhkannya (World Health Organization, 2020).

Menurut kamus daring Merriam-Webster, kata bahasa Inggris "infodemic" merupakan gabungan 2 kata benda bahasa Inggris, information (informasi) dan epidemic (epidemi) yang menunjuk pada cepat dan luasnya penyebaran informasi baik yang akurat maupun tidak akurat terkait suatu penyakit (Merriam-Webster, 2020). Kata infodemi pertama kali dicetuskan oleh David Rothkopf, seorang jurnalis dan ilmuwan politik dalam artikelnya pada Washingtong Post edisi 11 Mei 2003 ketika membahas epidemi penyakit SARS. Rothkopf menulis, "What exactly do I mean by the "infodemic"? A few facts, mixed with fear, speculation and rumor, amplified and relayed swiftly worldwide by modern information technologies, have affected national and international economies, politics and even security in ways that are utterly disproportionate with the root realities" (Rothkopf, 2003). Oleh karena menjadi gabungan informasi yang akurat maupun tidak, maka dampak infodemi justru terlihat lebih besar dibandingkan penyakit itu sendiri.

Secara luas, infodemi dapat dipahami sebagai misinformasi atau berita palsu (fake news) terkait epidemi yang menyebar dengan cepat dan mudah di dunia maya karena massifnya penggunaan aplikasi-aplikasi media sosial. Ekosistem media digital yang dihuni oleh warganet yang tidak melakukan penyaringan informasi secara kritis dengan mudah akan meningkatkan penyebaran infodemi. Amplifikasi realitas infodemik oleh aneka platform media sosial ini menjadikan wabah Covid-19 ini berbeda dari wabah SARS tahun 2003, H1N1 atau flu burung tahun 2009, MERS tahun 2012, dan Ebola (2014) (Kulkarni, Prabhu, D, \& Ramraj, 2020; Laato, Islam, Islam, \& Whelan, 2020).

Dampak infodemi yang paling terasa adalah massifnya kecemasan, kepanikan hingga kesalahan pengambilan keputusan hingga menimbulkan penyakit psikosomatik. Ini terjadi ketika seseorang mencapai titik lelah akibat tidak mampu memilah dan mengolah informasi sehingga timbul stres dan kecemasan berlebihan. Kondisi ini jika berlanjut dapat menimbulkan risiko laten berupa gangguan kesehatan mental (Krisdamarjati, Yohanes Advent; Chrysna, 2020; Kulkarni et al., 2020). Karena itu, pembacaan dan pemahaman atas realitas infodemik sangat diperlukan sebagai bagian dari langkah penanggulangan pandemi Covid-19 baik secara global maupun nasional.

Tulisan ini merupakan sebuah upaya membaca dan menganalisis realitas infodemi di Indonesia dengan mengolah kembali, menganalisis dan menyajikan kembali serta menafsir data dari mitra WHO terkait penanganan infodemi yakni Covid19 Infodemics Observatory tentang dinamika kicauan warganet Indonesia yang berhubungan dengan Covid-19. Data tersebut dapat diperoleh secara bebas pada laman https://covid19obs.fbk.eu/\#/. Covid19 Infodemics Observatory merupakan kegiatan riset melalui Complex Multilayer Networks (CoMuNe) Lab, yang adalah badan hasil kemitraan antara WHO dengan Fondazione Bruno Kessler (FBK atau Bruno Kessler Foundation) dengan misi utama membangun platform bigdata untuk memonitor penyebaran misinformasi dan disinformasi terkait Covid-19 di seluruh dunia secara real time. Badan kerja sama tersebut dipimpin oleh Dr. Manlio De Dominico, selaku ketua CoMuNe Lab pada FBK (Magazine.fbk.eu, 2020). Aktivitas Covid19 Infodemics 
Observatory ini dimulai sejak tanggal 21 Januari 2020 dengan berfokus pada kicauan atau tweets pada Twitter.

\section{Fenomena Global Infodemi Covid-19}

Salah satu analisis terhadap infodemik dalam skala global dilakukan oleh Covid-19 Infodemic Observatory dengan basis data cuitan pengguna Twitter sejak 21 Januari 2020 (https://covid19obs.fbk.eu/\#/). Hingga 22 Juli 2020, analisis telah dilakukan terhadap lebih dari 356,9 juta pesan di Twitter dengan menggunakan teknik machine learning. Teknik tersebut digunakan untuk menentukan sentimen psikologis kolektif (collective sentiment \& psychology), polusi media sosial karena robot (social bot pollution), dan berita-berita yang dapat dipercaya (news reliability). Dari 356,9 juta pesan tersebut, sebanyak 57,8\% dihasilkan oleh manusia, dan $42,2 \%$ dihasilkan oleh robot. Sementara itu, terdapat $71,5 \%$ merupakan berita yang layak dipercaya (reliable news) karena merujuk pada url media berita dan sumbersumber ilmiah, dan sebanyak 28,5\% merupakan berita tak layak dipercaya (unreliable news) (CoMuNeLab, 2020).

Derdasarkan data tersebut, menurut Covid-19 Infodemic Observatory, Indeks Resiko Infodemik (IRI) Covid-19 secara global per 22 Juli 2020 berada pada level 0,27. IRI adalah jumlah potensial pengguna twitter yang terpapar oleh berita tak layak dipercaya (unreliable news) dalam sehari. IRI hanya dapat dihitung jika jumlah tweets terkait pandemi melampaui 1000 tweets per hari. Rentang nilai IRI adalah antara 0 - 1. Jika dibaca dalam perspektif deskriptif, dari antar 1000 tweets per hari, sekitar 270 di antaranya berpotensi merupakan miinformasi yang berpotensi memapar sekitar 270 pengguna twitter dalam sehari. Sebuah angka yang mencengangkan dan patut diwaspadai.

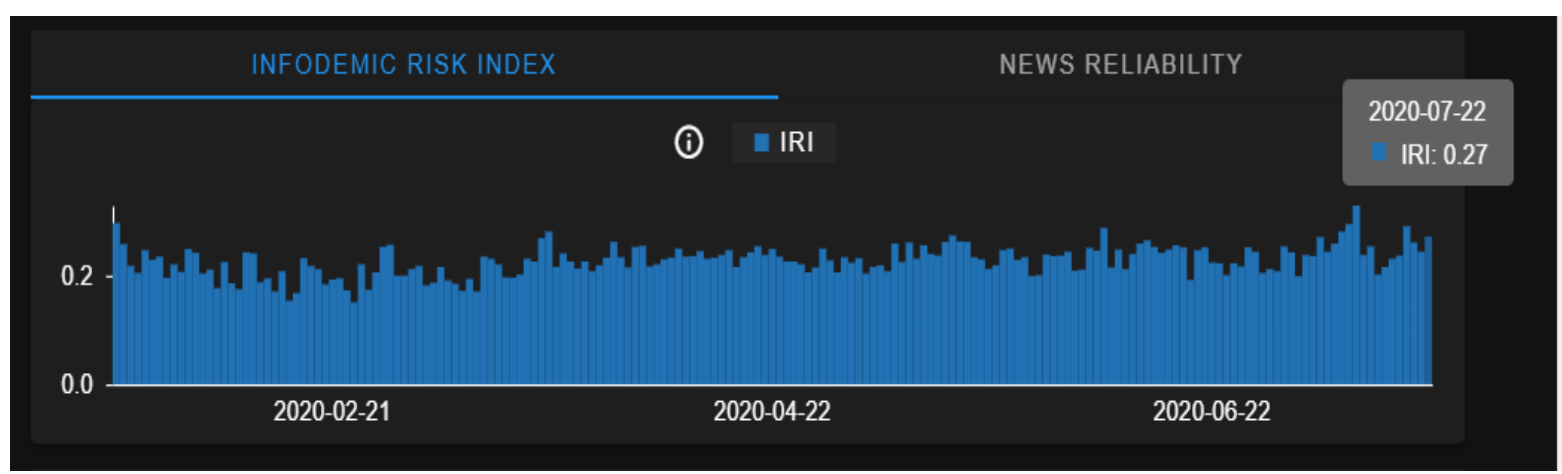

Grafik 1. Indeks Resiko Infodemi Covid-19 Global (21 Januari - 22 Juli 2020)

Sumber: Tankapan layar Website Covid-19 Infodemics Observatory

\section{Membaca Infodemi Covid-19 di Indonesia}

Penulis memotret dinamika infodemi di Indonesia dengan mengolah dan menyajikan kembali beberapa jenis data yang relevan dari kumpulan data tentang infodemi Covid-19 di Twitter yang telah dikumpulkan oleh Covid-19 Infodemics Observatory (Covid19obs).

Sebagai bagian dari data global, pengukuran data-data infodemik di Indonesia juga dihitung per hari sejak tanggal 21 Januari 2020 dan tersaji hingga tanggal 22 Juli 2020 ketika diakses pada tanggal 25 Juli 2020 pukul 11.00 WITA. Analisis dan penyajian data infodemik di 
Indonesia dilakukan penulis dengan melihat data-data terkait pada capaian nilai tertinggi pada setiap interval 1 bulan sejak 21 Januari 2020. Untuk merangkum data, penulis hanya mengambil 3 jumlah tweet tertinggi setiap bulan. Data-data tersebut akan dimaknai kembali dengan menghubungkannya dengan konteks peristiwa sosial, ekonomi, politik budaya terkait Covid-19 di Indonesia yang berlangsung di sekitar tanggal data bersangkutan.

\section{Jumlah Tweets \& Reliabilitas Berita Infodemik}

Selama kurun waktu 21 Januari 2020 - 22 Juli 2020, jumlah kicauan tertinggi dalam jagat Twitter di Indonesia terkait pandemi Covid-19 adalah 114.000 per hari yakni pada tanggal 15 Maret 2020. Jumlah kicauan terendah adalah 5650 per hari yang terekam pada tanggal 15 Februari 2020. Dengan demikian, sejak 21 Januari - 22 Juli 2020, minimal terdapat 5650 tweets per hari yang berkaitan dengan pandemi Covid-19. Sekalipun demikian, besarnya jumlah kicauan per hari tersebut tidak berbanding lurus dengan tingkat reliabilitas informasi yang terkandung di dalamnya.

Jumlah tweets yang layak dipercaya (reliable facts) tergolong sedikit, sementara itu, saat bersamaan, jumlah kicauan yang tidak layak dipercaya sebagai fakta (unreliable facts) juga masih banyak. Secara khusus, hasil pengolahan penulis atas data Covid19obs, dari 18 hari dengan jumlah tweets tertinggi periode 21 Januri - 22 Juli 2020 memperlihatkan adanya kesenjangan tersebut sebagaimana terlihat dalam tabel 1 \& grafik 2.

Tabel 1. Jumlah tweets infodemi \& news

\begin{tabular}{|c|c|c|c|}
\hline Hari & $\begin{array}{l}\text { Jumlah } \\
\text { Tweets }\end{array}$ & $\begin{array}{l}\text { Reliable } \\
\text { Facts }\end{array}$ & $\begin{array}{l}\text { Unreliable } \\
\text { Facts }\end{array}$ \\
\hline 25-Jan & 50.100 & 2.260 & 1.460 \\
\hline 26-Jan & 96.200 & 6.810 & 2.310 \\
\hline 27-Jan & 43.900 & 3.190 & 621 \\
\hline 02-Mar & 104.000 & 5.970 & 849 \\
\hline 15-Mar & 114.000 & 608 & 87 \\
\hline 22-Mar & 96.600 & 1.070 & 158 \\
\hline 8-Mar & 68.800 & 691 & 213 \\
\hline 29-Mar & 58.300 & 664 & 164 \\
\hline 01-Apr & 58.100 & 820 & 547 \\
\hline 09 Mei & 54.400 & 683 & 215 \\
\hline 15 Mei & 59.200 & 519 & 206 \\
\hline $18 \mathrm{Mei}$ & 85.100 & 605 & 180 \\
\hline 27 Mei & 54.300 & 634 & 123 \\
\hline 09-Jun & 56.200 & 560 & 108 \\
\hline 10-Jun & 49.500 & 453 & 99 \\
\hline 11-Jun & 43.100 & 257 & 100 \\
\hline 19-Jul & 52.500 & 405 & 130 \\
\hline 20-Jul & 48.500 & 634 & 83 \\
\hline 21-Jul & 39.800 & 687 & 107 \\
\hline
\end{tabular}

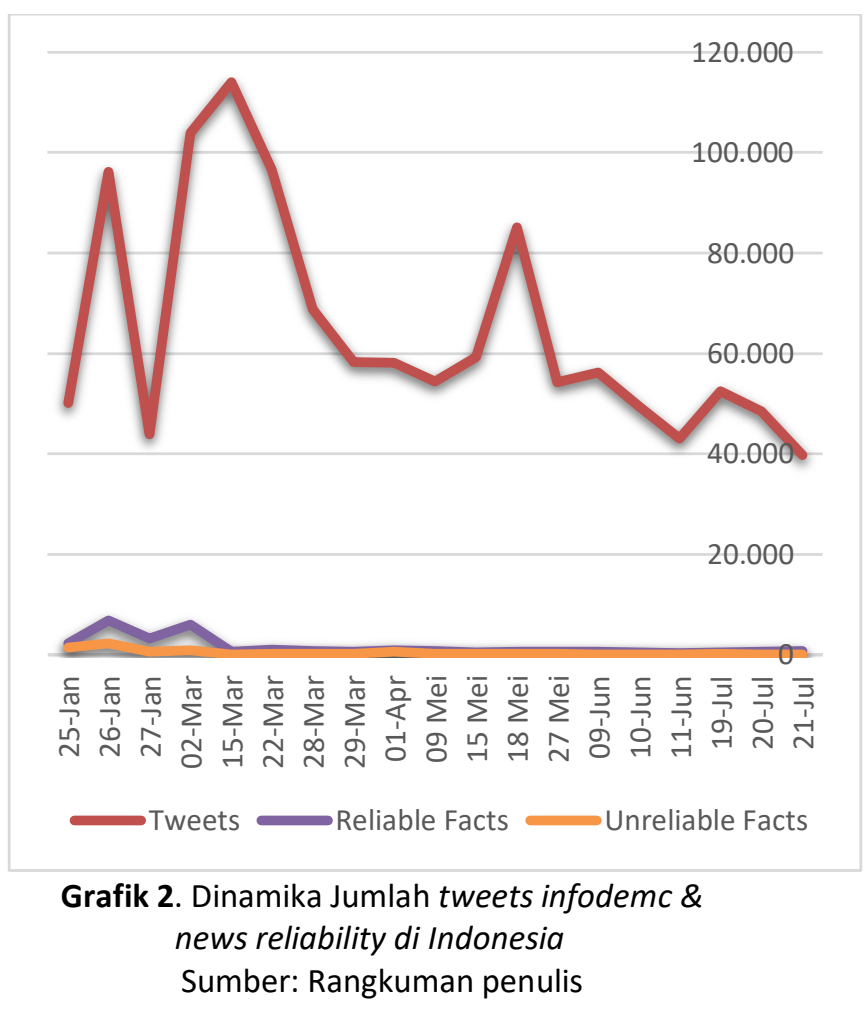


Tabel 1 \& Grafik 2 memperlihatkan bahwa jumlah tweet terkait pandemi Covid-19 dalam jumlah besar di Indonesia telah dimulai pada akhir bulan Januari 2020 dengan jumlah terbanyak adalah tanggal 26 Januari 2020 yakni sebanyak 96.200 tweets. Ramainya warganet Indonesia membicarakan Covid-19 pada akhir Januari dipicu oleh rencana dan aksi pemulangan sekitar 420 mahasiswa Indonesia dari wilayah kasus pertama Covid-19 di dunia yakni kota Wuhan, provinsi Hubei, Tiongkok (Medcom, 2020). Rencana maupun peristiwa pemulangan WNI dari kota Wuhan tersebut mendapat porsi pemberitaan yang besar dari media nasional mupun lokal di Indonesia. Sekalipun demikian, dari jumlah kicauan sebanyak itu, hanya sekitar 6.860 sebagai informasi yang reliable, dan sebanyak 2.310 tweets yang tidak reliable sebagai fakta.

Puncak tertinggi jumlah tweets terkait pandemi Covid-19 di Indonesia terjadi pada bulan Maret 2020 yakni sebanyak 104.000 tweets pada tanggal 2 Maret 2020, dan 114.000 pada tanggal 15 Maret 2020, dan 96.600 tweets tanggal 22 Maret 2020. Sebagaimana diketahui, bahwa penanda awal masuknya Covid-19 di Indonesia adalah ditemukannya kasus pasien positif Covid-19 pertama di Depok, Jawa Barat. Pengumuman mengenai kasus positif pertama ini diumumkan secara langsung oleh Presiden Joko Widodo dan Menteri Kesehatan Terawan Agus Putranto di Istana Negara tanggal 2 Maret 2020. Selain karena menjadi pusat perhatian media, massifnya jumlah kicauan tersebut merupakan dampak dari proyeksi ketakutan dan kecemasan warganet Indonesia setelah lebih dari 2 bulan sebelumnya berada dalam situasi yangt tidak pasti terkait apakah pandemi Covid-19 akan sampai di Indonesia.

Perdebatan tentang privasi pasien positif Covid-19 serta ketidakpastian informasi terkait upaya penanganan di Indonesia seperti perlu atau tidaknya lockdown serta munculnya sejumlah komentar tokoh publik terkait Covid-19, kompetisi antar para influencer, menjadikan terjadinya tsunami informasi pandemi Covid-19 pada bulan Maret 2020. Secara khusus, perang wacana kelompok pro lockdown yang identik dengan pihak oposisi pemerintah vs anti lockdown yang identik dengan pemerintah, menjadikan jagat media sosial Indonesia begitu riuh-rendah pada Maret 2020.

Saat bersamaan, desakan agar Menteri Kesehatan, Terawan mundur dari jabatannya karena dinilai tidak mampu menangani krisis pandemi dan menyepelekan Covid-19 juga menjadi amunisi informasi yang turut meramaikan infodemi Indonesia bulan Maret 2020. Beberapa media nasional bahkan ikut memberi frame pada wacana tersebut. Editorial harian Jakarta Post tanggal 14 Maret 2020 menulis, "This is already an emergency. Jokowi should remove anything or anyone, including his own officials, should they get in the way of country's efforts ti combat the pandemic" (Post, 2020). Sepuluh hari kemudian, tanggal 24 Maret 2020, harian Koran Tempo juga menulis editorial dengan judul yang lugas "Mundurlah Terawan" (Tempo, 2020). Editorial sebuah media merupakan pernyataan implisit dari sikap politik media di hadapan isu-isu tertentu. Dengan demikian, wacana desakan agar Terawan mundur dari jabatan Menteri Kesehatan menjadi salah satu isu kuat dalam pusaran wacana infodemik media termasuk media sosial bulan Maret 2020.

Massifnya kicauan pandemi Covid-19 pada bulan Maret 2020 tersebut tidak sebanding dengan reliabilitas informasinya. Dari 104.000 tweets tanggal 2 Maret 2020, hanya 5.970 yang 
terverifikasi sebagai layak dipercaya, dan hanya sebanyak 849 tweets yang terkonfirmasi sebagai berita yang tidak layak dipercaya. Lebih parah lagi, dari 114.000 tweets, hanya 608 tweets yang terkonfirmasi sebagai berita layak dipercaya, dan 87 tweets yang terverifikasi sebagai berita yang tidak layak dipercaya. Kondisi tidak sebanding antara jumlah tweets dengan reliabilitas beritanya tersebut berlangsung selama pandemi Covid-19 hingga Juli 2020.

Jika ditilik lebih lanjut dalam data Covid-19 Infodemics Observatory, reliabilitas berita yang rendah tersebut dipengaruhi juga oleh sumber tweets yang sebagiannya bukan dari manusia (humans) tetapi dari robot (bots); baik yang terverifikasi maupun tidak terverifikasi. Sebagai contoh, dari 104.000 tweets tanggal 2 Maret 2020, sebanyak 603 terverifikasi berasal dari bots (verified bots) dan 144 tweets dari manusia; sementara itu, sebanyak 70.400 tweets tidak terverifikasi sebagai user manusia (unverified humans) dan sebanyak 32.500 tweets tidak terverifikasi sebagai user bots (lihat Lampiran). Kesenjangan antara jumlah kicauan pandemi Covid-19 dengan reliabilitas informasinya tersebut semakin jelas jika dibaca dalam kaitan dengan data Indeks Resiko Infodemik (IRI) dari sumber yang sama tersebut.

\section{Indeks Resiko Infodemik Indonesia}

Indeks Resiko Infodemik (IRI) adalah jumlah potensial pengguna twitter (baca: warganet) yang dapat terpapar berita infodemik tak layak dipercaya (unreliable news) dalam sehari. IRI hanya dapat dihitung jika jumlah tweets terkait pandemi melampaui 1000 tweets per hari. Rentang nilai IRI adalah antara 0 - 1. Jumlah dan dinamika IRI Indonesia tampak dalam grafik 3.

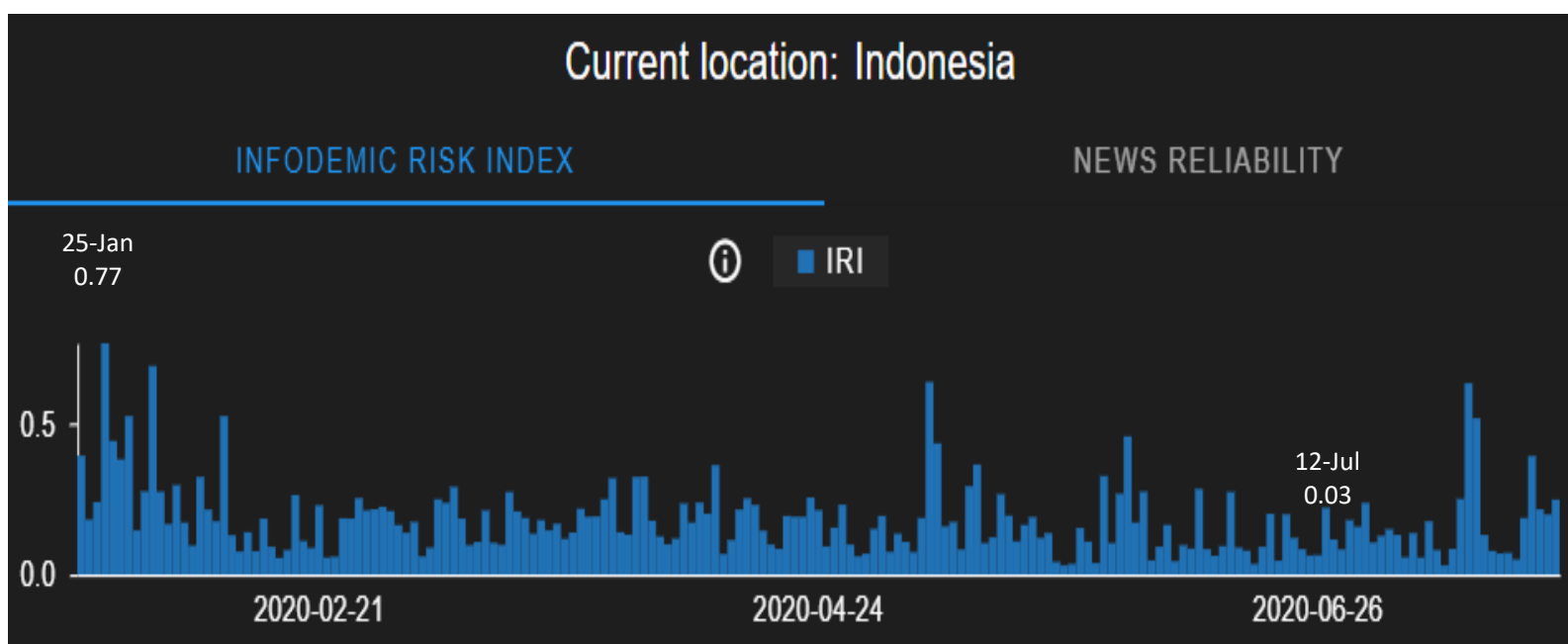

Grafik 3. Indeks Resiko Infodemik Covid-19 di Indonesia Periode 21 Januari - 22 Juli 2020 Sumber: Tangkapan Layar Website Covid-19 Infodemics Observatory (tambahan angka oleh penulis)

Grafik 3 memperlihatkan bahwa Indeksi Resiko Infodemik Covid-19 Indonesia tertinggi adalah 0,77 yang terjadi pada tanggal 25 Januari 2020, dan IRI terendah adalah 0,03 yang terjadi pada tanggal 12 Juli 2020 dari skala 0.00 - 1.00 untuk periode 21 Januari 2020 - 22 Juli 2020. Hal ini berarti, dari 1000 tweets terkait pandemi Covid-19 per hari, pada tarafterendah, sebanyak 30 warganet khususnya pengguna twitter di Indonesia beresiko terpapar informasi tidak layak dipercaya (unreliable news). Sedangkan pada taraf tertinggi mencapai 770 
pengguna twitter Indonesia yang berpotensi terpapar informasi tak layak dipercaya (unreliable news) dari 1000 tweets terkait Covid-19 per hari. Angka indeks resiko infodemik tersebut tergolong beresiko tinggi mengingat sifat penularan informasi pandemi yang juga bersifat eksponensial dengan laju yang lebih cepat ketimbang laju penularan virus penyebab Covid-19 itu sendiri.

\section{Penutup}

Infodemi Covid-19 merupakan banjir besar informasi, baik akurat maupun tidak, yang membuat orang kesulitan menemukan sumber dan panduan terpercaya saat mereka membutuhkannya untuk mengatasi Covid-19. Infodemi berdampak luas baik bagi kondisi fisik dan psikologis seseorang tetapi juga secara sosial dan politik pengambilan kebijakan untuk mengatasi gempuran pandemi Covid-19 yang begini dahsyat. Hasil himpunan data Covid19 Infodemics Observatiory menunjukkan bahwa secara global, sejak 21 Januari hingga 22 Juli 2020, telah lebih dari 365 juta tweets terkait Covid-19. Di Indonesia pun, puluhan ribu hingga ratusan ribu tweets terkait Covid-19 dihasilkan dalam sehari. Jumlah tertinggi yang dihasilkan adalah 114.000 per hari yakni pada tanggal 15 Maret 2020. Sekalipun demikian, jumlah tweets yang begitu banyak tersebut tidak didukung oleh tingkat reliabilitas beritanya. Masih terlalu sedikit kicauan yang terkategorikan sebagai reliable facts dan masih banyak yang tergolong sebagai unreliable facts. Hal inilah yang mengakibatkan masih tingginya Indeks Resiko Infodemik di Indonesia yang bahkan menyentuh level 0,77 pada tanggal 25 Januari 2020.

\section{Daftar Pustaka}

CoMuNeLab. (2020). Covid19 Infodemics Observatory. Retrieved July 25, 2020, from FBK-WHO Partnership website: https://covid19obs.fbk.eu/\#/

Krisdamarjati, Yohanes Advent; Chrysna, M. (2020). Infodemik tidak kalah bahaya dari Covid-19. Kompas.Id, pp. 1-23. Retrieved from https://interaktif.kompas.id/baca/bahaya-infodemik/

Kulkarni, P., Prabhu, S., D, S. K., \& Ramraj, B. (2020). Covid-19-infodemic overtaking pandemic? Time to disseminate facts over fear. Indian Journal of Community Health, 32(2 Special Issue), 264268.

Laato, S., Islam, A. K. M. N., Islam, M. N., \& Whelan, E. (2020). What drives unverified information sharing and cyberchondria during the COVID-19 pandemic? European Journal of Information Systems, 29(3), 288-305. https://doi.org/10.1080/0960085X.2020.1770632

Magazine.fbk.eu. (2020). FBK PARTNERS WITH WHO ON NEW INITIATIVE TO MONITOR COVID-19 INFODEMICS FROM AROUND THE WORLD - FBK Magazine. Retrieved July 29, 2020, from https://magazine.fbk.eu/en/news/fbk-partners-with-who-on-new-initiative-to-monitor-covid19-infodemics-from-around-the-world/

Medcom. (2020). KBRI Disebut Siapkan Pemulangan Mahasiswa di Wuhan - Medcom.id. Retrieved July 29, 2020, from https://www.medcom.id/nasional/daerah/9K5rv4BN-kbri-disebut-siapkanpemulangan-mahasiswa-di-wuhan

Merriam-Webster. (2020). Infodemic: An Epidemic of Information | Merriam-Webster. Retrieved July 29, 2020, from https://www.merriam-webster.com/words-at-play/words-were-watchinginfodemic-meaning

Post, J. (2020). Terawan must go, civil groups say, demanding crisis-sensitive health minister - 
National - The Jakarta Post. Retrieved July 29, 2020, from https://www.thejakartapost.com/news/2020/03/17/terawan-must-go-civil-groups-saydemanding-crisis-sensitive-health-minister.html

Rothkopf, D. J. (2003). When the Buzz Bites Back - The Washington Post. Retrieved July 29, 2020, from https://www.washingtonpost.com/archive/opinions/2003/05/11/when-the-buzz-bitesback/bc8cd84f-cab6-4648-bf58-0277261af6cd/

Tempo, K. (2020). Mundurlah Terawan - Editorial - koran.tempo.co. Retrieved July 29, 2020, from https://koran.tempo.co/read/editorial/451250/mundurlah-terawan

World Health Organization. (2020). Novel Coronavirus. In World Health Organization Situation Report 13. Retrieved from https://www.who.int/docs/default-source/coronaviruse/situationreports/20200202-sitrep-13-ncov-v3.pdf 
Lampiran: Tangkapan layar Grafik Lengkap Infodemi di Indonesia Menurut Covid-19 Infodemics Observatory, Periode 21 Januari 2020 - 22 Juli 2020 (diakses tanggal 25 Juli 2020 dari https://covid19obs.fbk.eu/\#/).
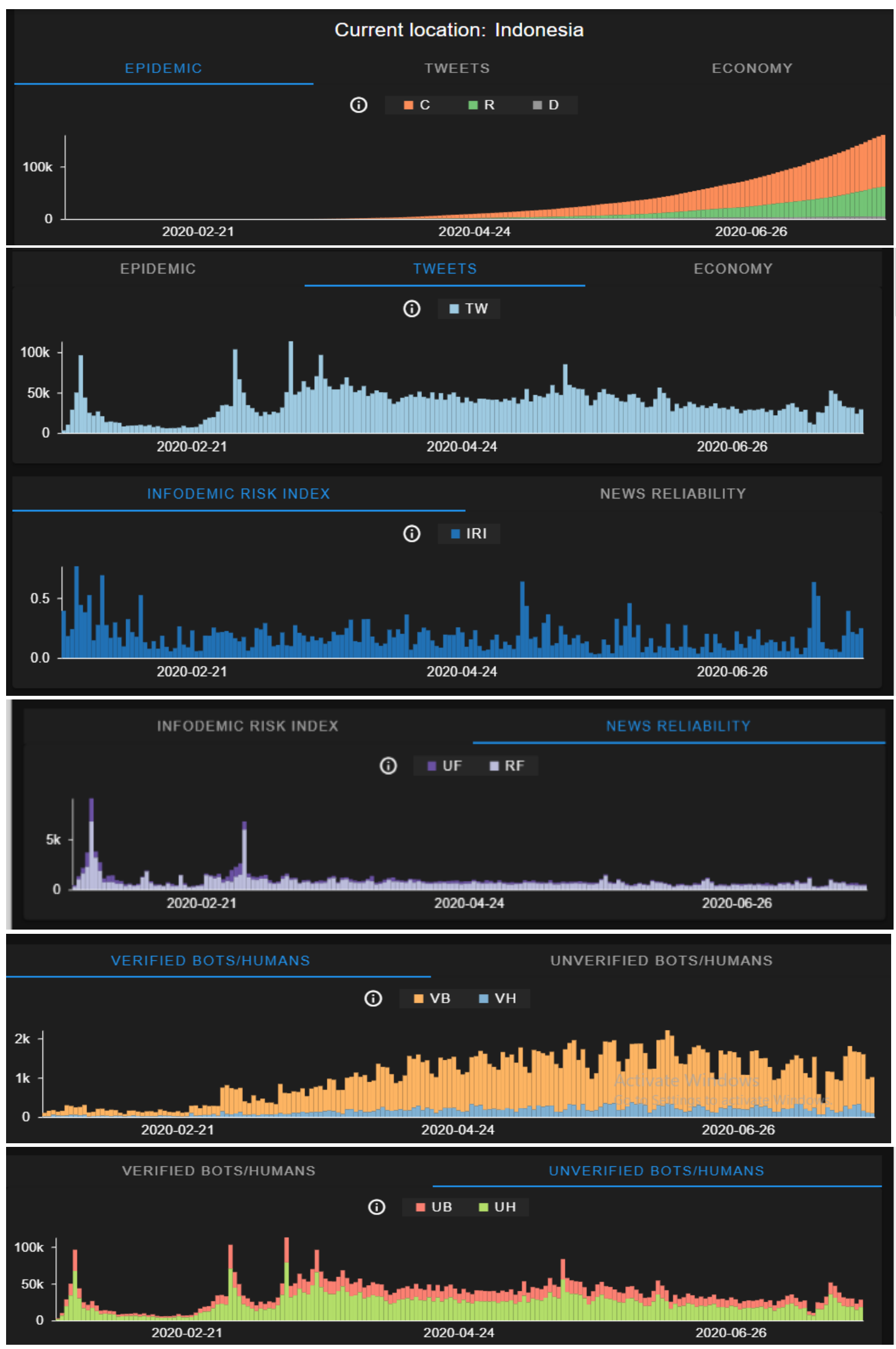